\title{
MATERIAL FLOW ANALYSIS OF ALUMINIUM IN A DYNAMIC SYSTEM: JERAM SANITARY LANDFILL
}

\author{
Agamuthu P., Venu Mahendra M. S.* \& Mohd Afzanizam M. \\ Institute of Biological Sciences, Faculty of Science, University of Malaya 50603 Kuala Lumpur, Malaysia \\ *unev_86@hotmail.com (Corresponding author) \\ Received on 15th December 2011, accepted in revised form 1st March 2011.
}

\begin{abstract}
Jeram Sanitary Landfill (JSL) receives waste from seven major municipalities, mostly from Kuala Lumpur and Selangor Municipality. The types of waste received are domestic waste, bulky waste and garden waste only. Currently, an average of 2100 tonne of solid waste per day from 470 compactors were landfilled daily at JSL. Each compactor disposed 4.6 tonnes which gives estimated at 766,500 tonnes in 2010. Out of this amount, 9.25 tonnes of $\mathrm{Al}$ end up in landfill per year. Most of the aluminum can are sent for recycling with approximately 1.39 tonnes/day. The leaching quantified through both gas and leachate was at 0.42 tonnes/day and 0.14 tonnes/day respectively. From the gas leaching, about 0.34 tonnes/day was released from the soil while 0.12 tonnes/day escaped through evaporation. Al in soil was quantified highest at near surface. This was identified as sink of the whole Al system. A major problem of sanitary landfill is the assessment of element transfers from inputs to outputs as a function of time due to the dynamic nature of the landfill activities.
\end{abstract}

(Keywords: Aluminium, Jeram landfill, Solid Waste Composition, Material Flow)

\section{INTRODUCTION}

The population explosion has indirectly contributed to the increase in waste generation. There may be a need for development and implementation of new tools, techniques and approaches in municipal environmental management, in order to fulfill their roles in management for sustainability (Öman, C, 1991).The most common way of disposing such waste is on to the landfill. Only a few countries employ the habit of recycling, incinerator and other means of waste disposal in integrated ways. Thus, to ensure the longevity of their environment, landfill management of waste both quantitatively and qualitatively has been a serious concern. A good approach to rectify the scenario towards best landfill management is through establishing the influx and out flux of the landfill system.

Material Flow Analysis (MFA) is a method that studies the fluxes of resources used and transformed as they flow through a region defined in space and time (Brunner and Rechberger, 2004). It connects the sources, the pathways and the intermediate and final sinks of a material. Because of the law of the conservation of matter, the results of an MFA can be controlled by a simple material balance comparing all inputs, stocks and outputs and processes. It is this distinct characteristic of MFA that makes the method attractive as a decision-support tool in resource management, waste management and environmental management (Brunner and Rechberger, 2004). MFA is proved to be a suitable instrument for early detection of environmental problems and development of appropriate measures in industrialized countries (Baccini and Brunner, 1991). Examples of application are resource management planning at city and regional level, waste management planning, the development of environmental management systems in enterprises and the derivation of indicators as a basis for monitoring sustainable development. MFA has already been integrated in urban areas of developing countries in the field of environmental sanitation (Binder, 1996; Belevi, 2002; Montangero et al., 2004).

MFA or Substance Flow Analysis (SFA) was originally developed back in 1950's (Baccini and Brunner 1991) and elemental analysis of specific interest were studied in various aspect using MFA as a tool. Bergback et. al (2001) studied material flow of several metals such $\mathrm{Cd}$ and $\mathrm{Cr}$ in Stockholm, Sweden. The flow of $\mathrm{Cu}$ in Europe was investigated by several studies through a lifecycle approach from extracting ore, through processing and manufacturing, to solid waste management or recycling (Graedal et.al.,2002; Bertram et.al., 2002). MFA in municipal solid waste management is discussed in a comprehensive guideline (Vienna University of Technology, 2000). Aluminum is an abundant metallic chemical element which is widely used throughout the world for a wide range of products. Many consumers interact with some form 
of $\mathrm{Al}$ on a daily basis, especially if they are active in the kitchen. Aluminum's natural resistance aids it in its role in packaging (and many other areas), as unlike in iron, aluminum oxide forms a protective, and not destructive layer. Aluminum is also completely impermeable, (even when rolled into extremely thin foil). Aluminum has only one naturally occurring isotope, aluminium-27, which is not radioactive. The use of aluminum exceeds that of any other metal except iron. Recovery of this metal from scrap (via recycling) has become an important component of the aluminum industry. Industrial production world-wide of new metal is around 20 million tonnes per year, and a similar amount is recycled. $\mathrm{Al}$ is commonly known as an innocent compound (Marlen et al 2007). But still, when one is exposed to high concentrations, it can cause health problems.

The water-soluble form of aluminum causes the harmful effects, and these particles are called ions. They are usually found in a solution of aluminum in combination with other ions, for instance as aluminum chlorine. It is intriguing when $\mathrm{Al}$ escapes away as leachate or via air-borne, which may give effect for workers. They may endure lung problems when they breathe in aluminum dust (Chen et al, 2010). The effects of aluminum have drawn our attention, mainly due to the acidifying problems (Chen et al, 2010). Aluminum may accumulate in plants and cause health problems for animals that consume these plants. Another negative environmental effect of aluminum is that its ions can react with phosphates to form aluminum phosphate, which causes phosphates to be less available to water organisms.

The aim of this study is to establish the Al flows within a MFA framework in a sanitary landfill. Previous studies on $\mathrm{Al}$ are from either a small system such as the industry (production) itself or general systems such looking into the flows of $\mathrm{Al}$ in country scale. It is relatively new to use this MFA approach in confined yet dynamic system, such as landfill. This paper quantified $\mathrm{Al}$ flow in a sanitary landfill system by considering waste-input output analysis, mass balancing of $\mathrm{Al}$ flow, $\mathrm{Al}$ elemental flow in temporal and spatial system boundary and the total Substance Flow Analysis (SFA) of $\mathrm{Al}$ from a sanitary landfill in Malaysia. The results of the models are reported annually in the Aluminium for Future Generations sustainable development indicator reports (IAI 2008). At present, most oral and written presentations by and about the aluminum industry include references to material flow models such as the one shown in Fig 1.
Aluminum associations around the world represent bauxite miners and alumina refiners, primary and recycled $\mathrm{Al}$ producers, and downstream fabricators. These associations promote the contributions, that the aluminum industry and its products make to sustainable development while maintaining and improving the image of the industry. In the case of a material in increasing demand, with potentially longlife products and with inherent recyclability, such as $\mathrm{Al}$, maximization of its environmental benefit comes from increased recycling of products at the end of their useful life.

\section{MATERIAL AND METHODS}

\section{Field site and system boundaries}

The field study was carried out from January 2010 until December 2010, at Jeram Sanitary Landfill, located at Lot No. 1595, 2958, 2959 in Jeram Town, Kuala Selangor District. Former land-use was agriculture. The landfill is currently awarded a 25 years privatization-cum-concession for the construction; operation and maintenance of a 160acres area. The landfill receives an average 2100 tonnes of municipal solid waste per day. The types of waste received are domestic waste, bulky waste and garden waste only. The landfill caters for seven major municipalities in Klang Valley namely Kuala Selangor, Subang Jaya, Klang, Petaling Jaya, Shah Alam, Ampang Jaya and Selayang. JSL started its operation on $1^{\text {st }}$ January 2007 with 16 -years expected lifespan depending on the amount of wastes received.

\section{Sampling of Solids}

Waste segregation was done to determine quantity and quality of waste composition deposited at the landfill sites. The segregation work was done by sorting the waste according to the classification by Tchobanoglous et. al.1994. This was done by separating waste from randomly selected compactors delivered to the sites into four portions and each portion was further divided into another four portions until the weight of each portion was around $100 \mathrm{~kg}$. For laboratory analysis purpose, solid waste samples are taken at random. At each sampling occasion, four soil samples were collected at random using a shovel of $15 \mathrm{~cm}$ deep. Soil samples taken were topsoil (depth less than $15 \mathrm{~cm}$ ), mid-depth (between 15 to $30 \mathrm{~cm}$ depth) and depth above $30 \mathrm{~cm}$ at a active Cell 20. Then the soil was dried at $45^{\circ} \mathrm{C}$ for 3 days and powdered in laboratory. Element analysis was done for Al using Inductive-Coupled Plasma Optical Emission Spectrometry (ICP-OES) machine. Quality and quantity of rainfall at Jeram Sanitary Landfill was acquired. 


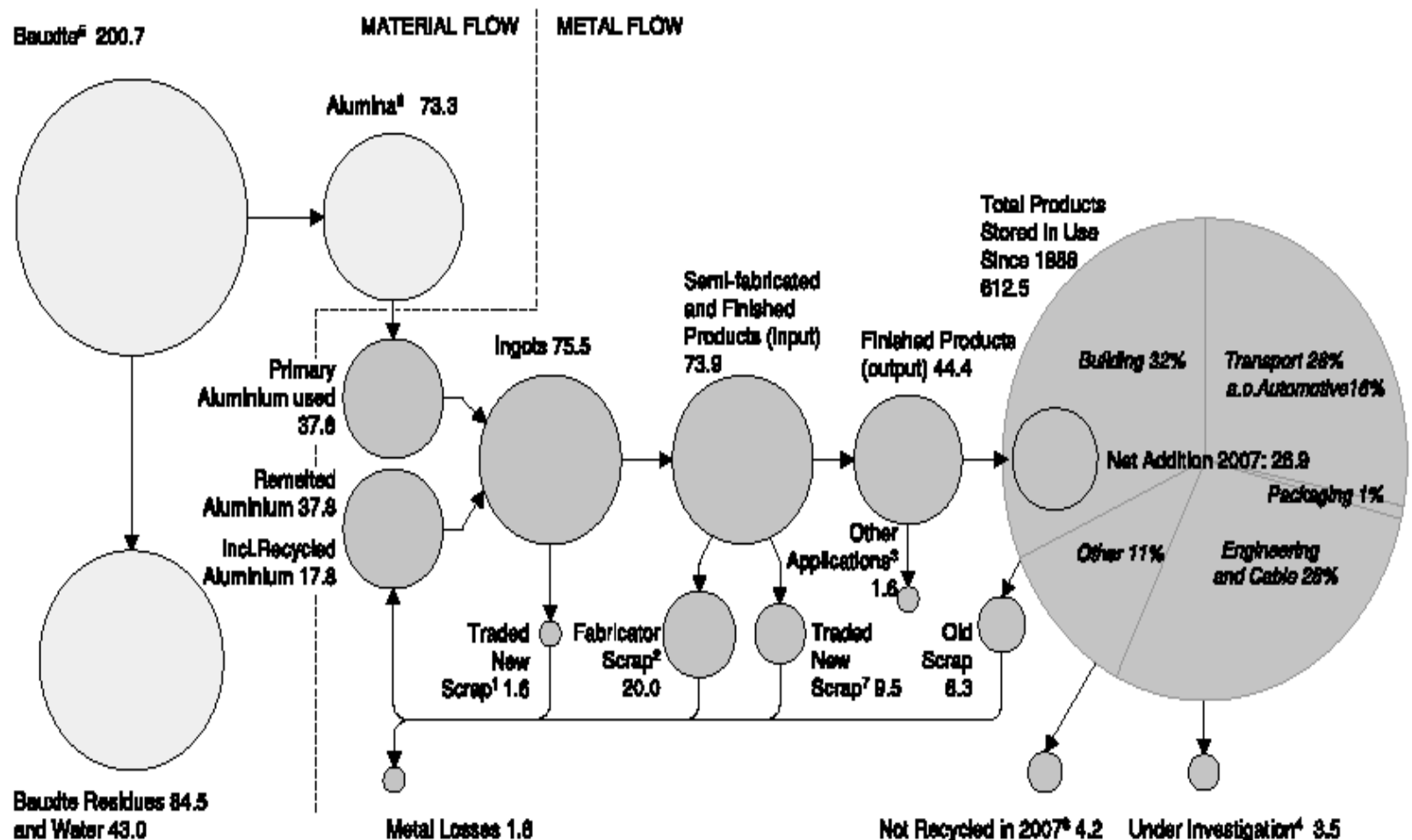

Figure 1: Global Al Flow in 2007 (Marlem Bertram, 2009)

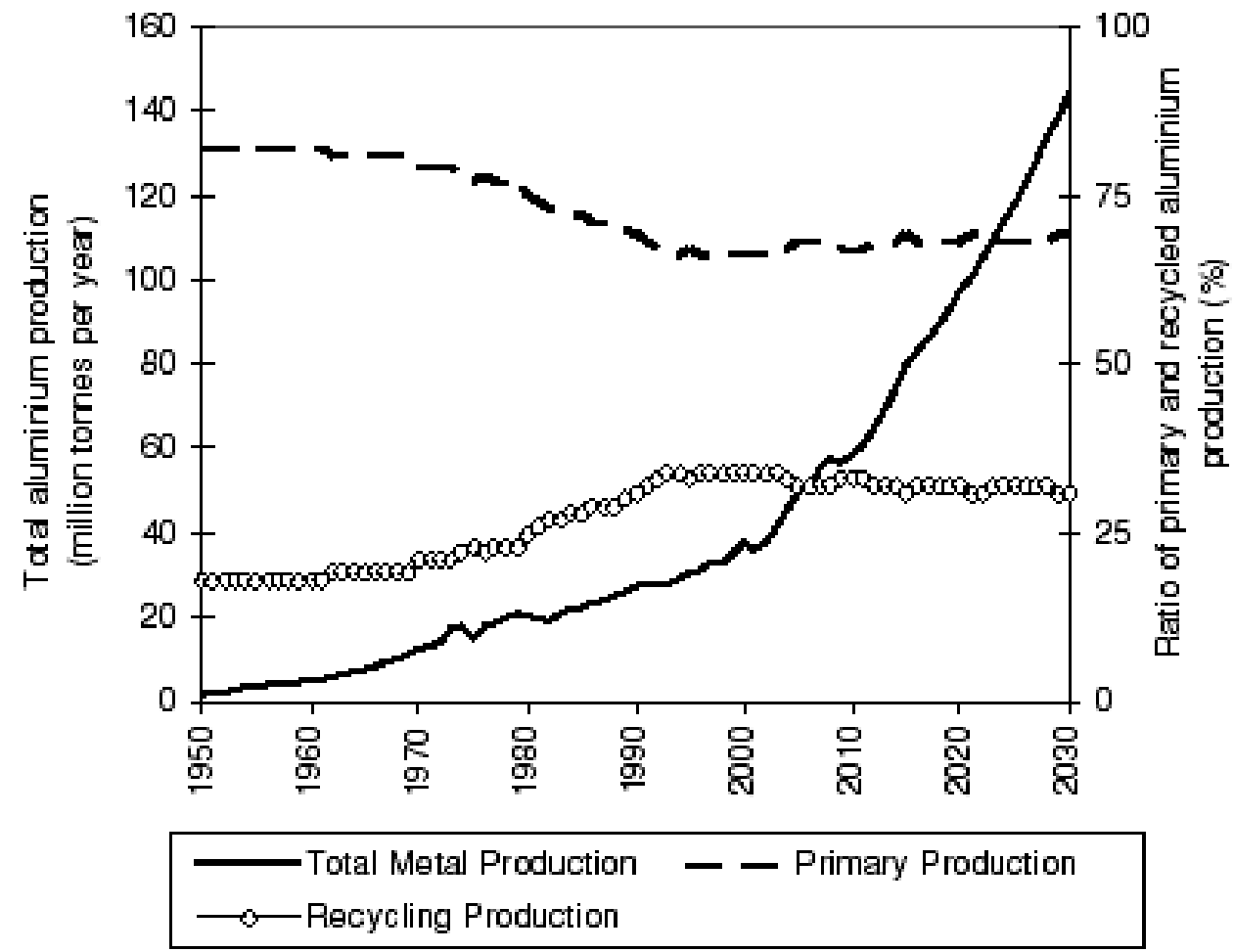

Figure 2: Global share of recycled and primary $\mathrm{Al}$ in million tonnes per year. 


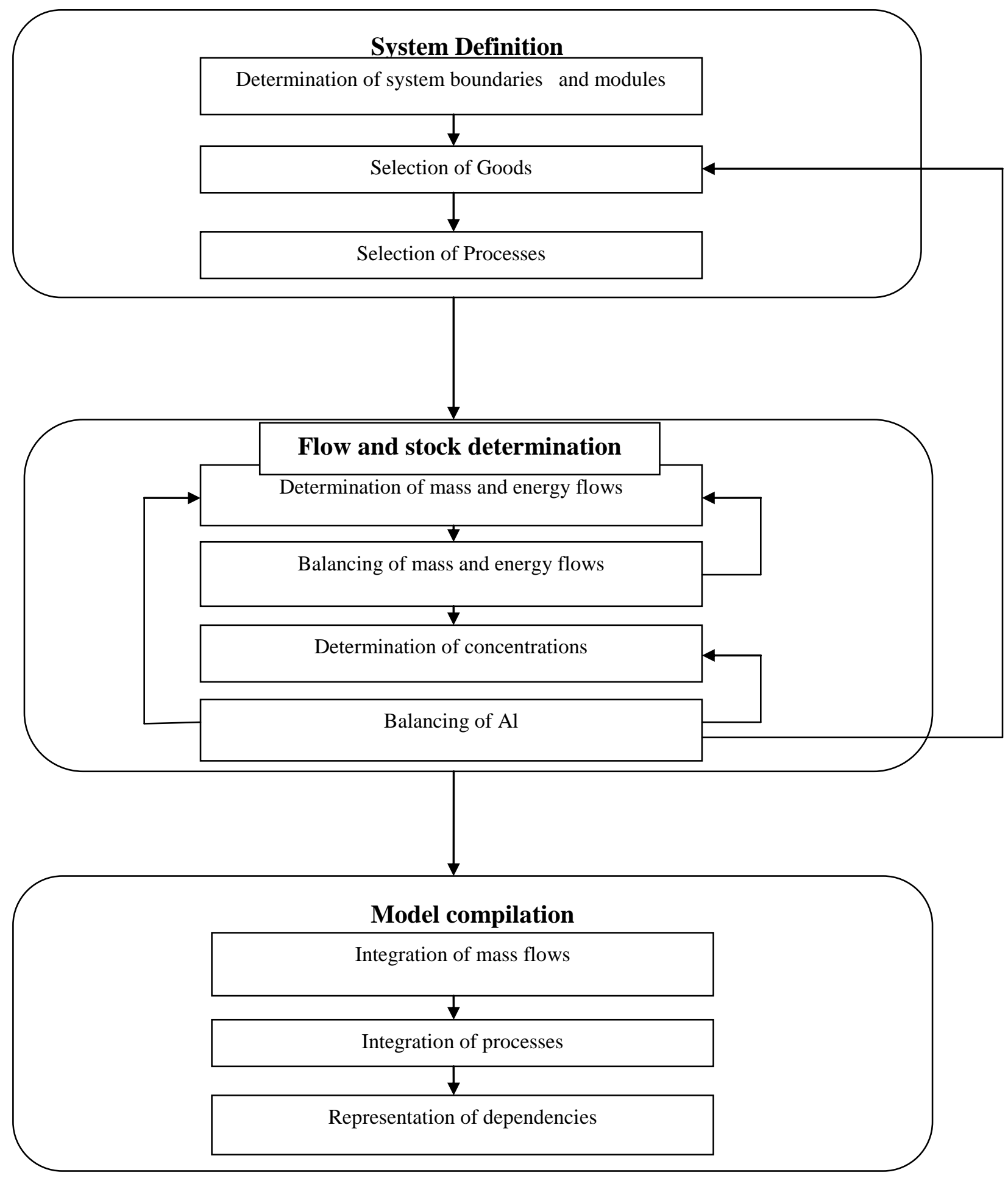

Figure 3: Proposed procedure for the analysis (Brunner and Rechberger, 2004, modified).

The nearest weather station is at Mardi Tanjong Karang Latitude $3^{\circ} 28^{\prime} \mathrm{N}$, Longitude $101^{\circ} 08^{\prime} \mathrm{E}$ and height above Mean Sea Level (MSL) is $2.4 \mathrm{~m}$. The daily rainfall amount (0800-0800 Malaysian Standard Time) for a particular day is the amount collected over the 24-hour period beginning from 0800 am on 
the day and was collected from here. Raw leachate was collected from Lagoon 1 and kept inside Schoot bottle. Digestion and biological parameters were done ex-situ. Al on leachate was tested and detected using ICP-OES.

\section{Mass Balance Analysis}

Material flow analysis (MFA) and substance flow analysis (SFA) were performed by means of the mass-balance model using Excel and STAN to analyze material flow performance, which follows the Austrian Standard ÖNorm 2096 S (MFA Application in Waste Management) ( Cencic and Rechberger, 2008). The modeling used was to give a simple understanding of material flow in a predefined system. The uncertainty of concentrations in the waste input was calculated based on data from Boldrin (2009) (as percentage of dry matter in the input mass); $\mathrm{Al}= \pm 12.0 \%$ unless stated otherwise. The uncertainties of concentrations in the outputs were assumed to be 5\% (Boldrin, 2009).

Gas emission measurement

Sampling of the gases at site was done in-situ using Tedlar bag at the valve tip of gas well and gas flaring unit. Analysis in the laboratory was done to determine concentration using Gas Chromatograph (ICP-MS model Perkin Elmer Optima 4300DV) to detect traces of $\mathrm{Al}$ in the gas form.The spatial system boundaries for this study includes the landfill body, landfill surface and processes or cycles within tropical sanitary landfill loop (Fig. 3). This system includes facilities for gas and leachate treatment. Time boundaries are set at one year. The system boundaries does not include the collection and transportation of waste to and from landfill. Presentation of product and material flows using the method of material flow analysis was done.

\section{RESULTS AND DISCUSSION}

\section{Composition of biomass in Jeram MSW}

Biomass materials, i.e. paper, food and yard wastes, wood, leather and textiles constitute $62 \%$ of the MSW (Table 1). The rest are inorganic materials such as metals, glass, gypsum/asbestos from construction and other minerals. The results show that the highest percentage of the waste disposed in JSL is organic waste, which includes kitchen waste $(32 \%)$. This is typically similar to other countries of developing and developed, as accounted by World Bank, 2011.

Table 1: Waste composition (based on on-site segregation) in Jeram Sanitary Landfill (2010).

\begin{tabular}{|c|c|c|c|c|}
\hline Type of Waste & $\begin{array}{c}\text { Collected } \\
\text { Amount } \\
\text { [tonne/day] }\end{array}$ & $\begin{array}{c}\text { Waste } \\
\text { composition } \\
\text { (Percentage by } \\
\text { wet weight basis, } \\
\text { \%) }\end{array}$ & $\begin{array}{l}\text { Typical waste } \\
\text { composition in } \\
\text { developing } \\
\text { countries } \\
\text { (World Bank, } \\
\text { 2011) }\end{array}$ & $\begin{array}{l}\text { Typical waste } \\
\text { composition in } \\
\text { developed } \\
\text { countries } \\
\text { (World Bank, } \\
\text { 2011) }\end{array}$ \\
\hline Organic Waste & 52.30 & 32.38 & 58 & 50 \\
\hline Hard Paper & 21.00 & 13.00 & $15^{*}$ & $20 *$ \\
\hline Soft Plastic & 18.60 & 11.52 & - & - \\
\hline Hard Plastic & 13.80 & 8.54 & $11 *$ & $9 *$ \\
\hline Soft Paper & 11.60 & 7.18 & - & - \\
\hline Debris & 10.00 & 6.19 & - & - \\
\hline Glass & 9.70 & 6.00 & 2 & 3 \\
\hline Wood & 9.00 & 5.57 & 2.9 & - \\
\hline Textile & 6.01 & 3.72 & 1.3 & - \\
\hline Tin/Alloy & 5.00 & 3.12 & - & - \\
\hline Polystyrene & 1.96 & 1.21 & - & - \\
\hline Aluminium Cans & 1.63 & 1.01 & - & - \\
\hline Electronics (Wires) & 0.50 & 0.31 & - & - \\
\hline Metal & 0.40 & 0.25 & 3 & 5 \\
\hline Others (Miscellaneous) & - & - & - & - \\
\hline TOTAL & 161.5 & 100 & - & - \\
\hline
\end{tabular}

* Hard paper and Soft paper are shown generally as Paper by World Bank, 2011.

* Hard plastic and Soft plastic are shown generally as Plastic by World Bank, 2011. 
The Al content differs in different solid waste components as shown in Table 2. The highest content of aluminum was seen in paper in general and nylon type of materials. The paper show high traces of $\mathrm{Al}$ due to the ink or labels values written on paper besides the property of the hard paper which has traces of Al (Nikolaas et al. 1997).

ICP was done for these ink materials, which gave out a significant value of $1.65 \pm 1.05 \mathrm{mg} / \mathrm{l}$ of $\mathrm{Al}$. This ink material was collected from the landfill itself, which may have it's value deteriorated over some time and reaction to the surroundings. Fresh ink analysis gave out $19 \%$ content of $\mathrm{Al}$. The concentration of $\mathrm{Al}$ for all solid waste samples were purely based on samples taken from landfill and not from production process. The contribution of $\mathrm{Al}$ to the whole landfill is not of solely on the percentage content of aluminium in solid waste. Percentage of Al contribution is based on the weightage of waste component present in the landfill itself. This data was very much dependent on the composition of solid waste in Jeram landfill. From Table 3, it is seen that the main contributors are soft plastics, hard papers (packaging papers) and organic waste (non-fruits based) with contributions at $12 \%, 10 \%$ and $11 \%$, respectively.

Table 2: Concentration of $\mathrm{Al}$ in different types of solid waste.

\begin{tabular}{|c|c|}
\hline Sample (solid waste components) & Concentration of $\mathrm{Al}$ \\
\hline Cloth & $0.35 \pm 0.05 \mathrm{mg} / \mathrm{l}$ \\
\hline Nylon & $76.50 \pm 0.12 \mathrm{mg} / \mathrm{l}$ \\
\hline Wires & $5.70 \pm 0.11 \mathrm{mg} / \mathrm{l}$ \\
\hline Paper (Soft) & $22.80 \pm 0.05 \mathrm{mg} / \mathrm{l}$ \\
\hline Paper (Hard) & $131.25 \pm 1.53 \mathrm{mg} / \mathrm{l}$ \\
\hline Glass & $13.77 \pm 0.13 \mathrm{mg} / \mathrm{l}$ \\
\hline Plastic & $1.572 \pm 0.22 \mathrm{mg} / \mathrm{l}$ \\
\hline Polystyrene & $1.865 \pm 0.15 \mathrm{mg} / \mathrm{l}$ \\
\hline Asbestos & $15.59 \pm 0.12 \mathrm{mg} / \mathrm{l}$ \\
\hline Garden Waste & $2.70 \pm 1.25 \mathrm{mg} / \mathrm{l}$ \\
\hline Kitchen Waste & $11.15 \pm 1.15 \mathrm{mg} / \mathrm{l}$ \\
\hline
\end{tabular}

*All solid waste samples are taken directly from landfill. 
Table 3: Percentage of Aluminum contributing to $\mathrm{Al}$ in flow solely from solid waste

\begin{tabular}{|c|c|}
\hline Types of Waste & Percentage of $\mathrm{Al}$ \\
\hline Aluminum can & 2 \\
\hline Cloth & 4.5 \\
\hline Debris & 5.5 \\
\hline Garden waste (leaves branches) & 8 \\
\hline Glass & 5.5 \\
\hline Hard Paper (boxes) & 5 \\
\hline Hard plastic & 4 \\
\hline Kitchen waste & 7 \\
\hline Organic waste (fruits) & 4 \\
\hline Organic waste (non fruits) & 11 \\
\hline Packaging paper & 10 \\
\hline Paper (soft) & 4 \\
\hline Pipes & - \\
\hline Plastics (hard) & 2 \\
\hline Plastics (soft) & 12 \\
\hline Polistyerene & 1 \\
\hline sanitary waste & 3 \\
\hline Shoes & 1 \\
\hline Tin & 5 \\
\hline Wire & 0.5 \\
\hline Wood & 5 \\
\hline Total & 100 \\
\hline
\end{tabular}

\section{In Flow of Aluminum in landfill.}

$\mathrm{Al}$ in-flows are from solid waste, precipitation and "others", which includes non scheduled waste contribution. Figure 4 clearly shows that solid waste the main contributor with $96 \%$, as quantified using STAN. Precipitation as a contributor is significant at $3 \%$. The $\mathrm{Al}$ content is quantified at $0.03 \pm 20.15 \mu \mathrm{g} / \mathrm{l}$. The main source of such metal to be detected in rain is in the form of aluminum debris (John 2007). 


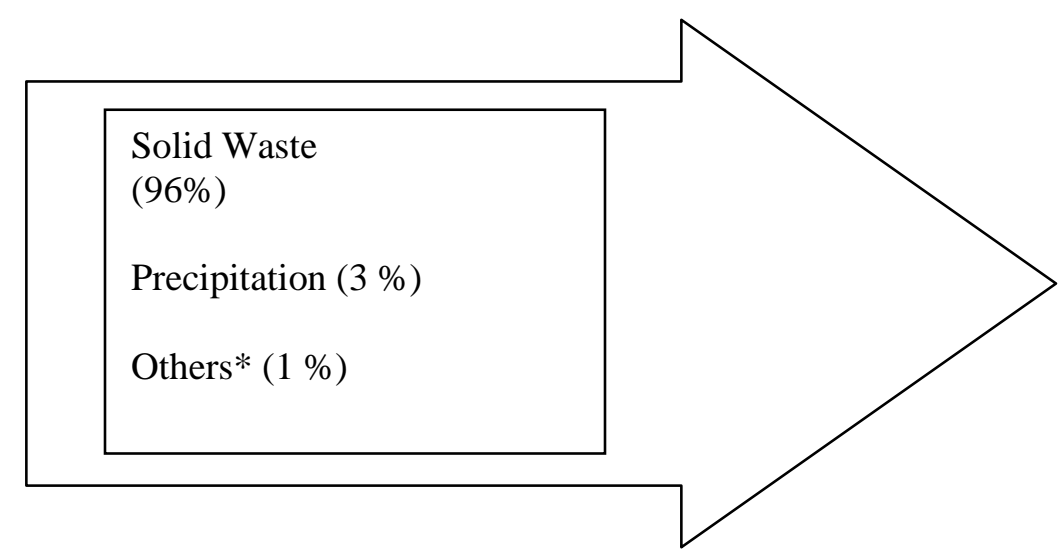

*Others include other non-scheduled wastes from municipality or company.

Figure 4: Contributors for $\mathrm{Al}$ input of the system.

Aluminum debris reacts with water, releasing a mixture of gases (including, among others, hydrogen, acetylene, and ammonia), which spontaneously ignites on contact with air and contact with damp air results in the release of copious quantities of ammonia gas, giving a "side-effect" of the whole scenario (Dohmeier 1996).

Besides daily input of solid waste from the local municipal, the Jeram landfill also caters for nonscheduled wastes such as animal crops and company waste (eg Cadbury chocolate). This type of waste is not frequent but occasionally it is significant, resulting in $1 \% \mathrm{Al}$ in average.

\section{Out Flow of Aluminum in landfill.}

In term of outflow of $\mathrm{Al}$ from the defined boundary of Jeram landfill, leachate and evapotransiration or formation of debris were identified as the main outsource. Figure 5 shows that high percentage $\mathrm{Al}$ lost in soil collection, as out-flow. However, this is not taken into consideration as outflow due to the collection for a period of time (as sink) for the system. The high percentage of Al was probably due to the reduction of $\mathrm{Al}$ in the form of tetrahydroxoaluminate $\mathrm{Al}(\mathrm{OH})_{4}^{-}$to metallic aluminum by bacteria, as proposed by Chen et al. 2011. The Jeram landfill has a flat topography with tropical climate, resulting in high amount of precipitation with maximum of $3000 \mathrm{~mm}$ per year and ambient temperature between $37^{\circ} \mathrm{C}$ and $40^{\circ} \mathrm{C}$. This condition results in a stable transpiration and evapotranspiration rate (equivalent).

Figure 6 shows that different soil depths results in different concentration of Al. Chen et al. 2011 also proposed that certain bacteria work more efficiently in breaking down the $\mathrm{Al}(\mathrm{OH})_{4}{ }^{-}$at higher temperature, which relates in higher Al at surface. Soil depth nearer to surface is generally at higher temperature at most times. Al in leachate was quantified at $2.40 \pm$ $3.23 \mathrm{mg} / \mathrm{l}$ (samples at site) and $1.69 \pm 0.82$ (samples from holding pond) in average which significantly contributes to about $30 \%$ of the $\mathrm{Al}$ output.

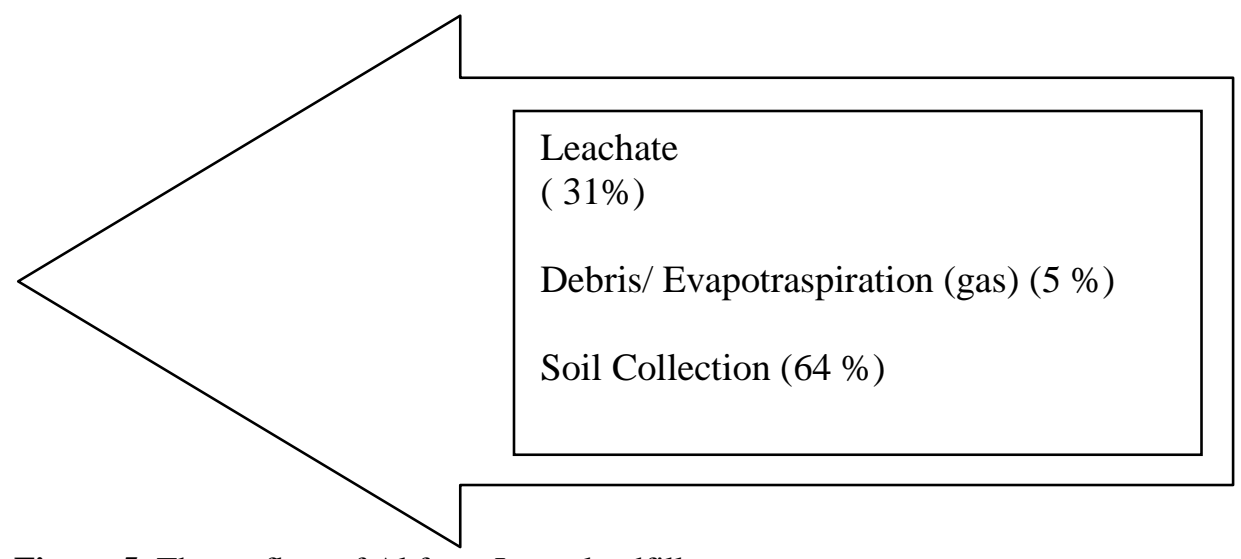

Figure 5: The outflow of $\mathrm{Al}$ from Jeram landfill. 


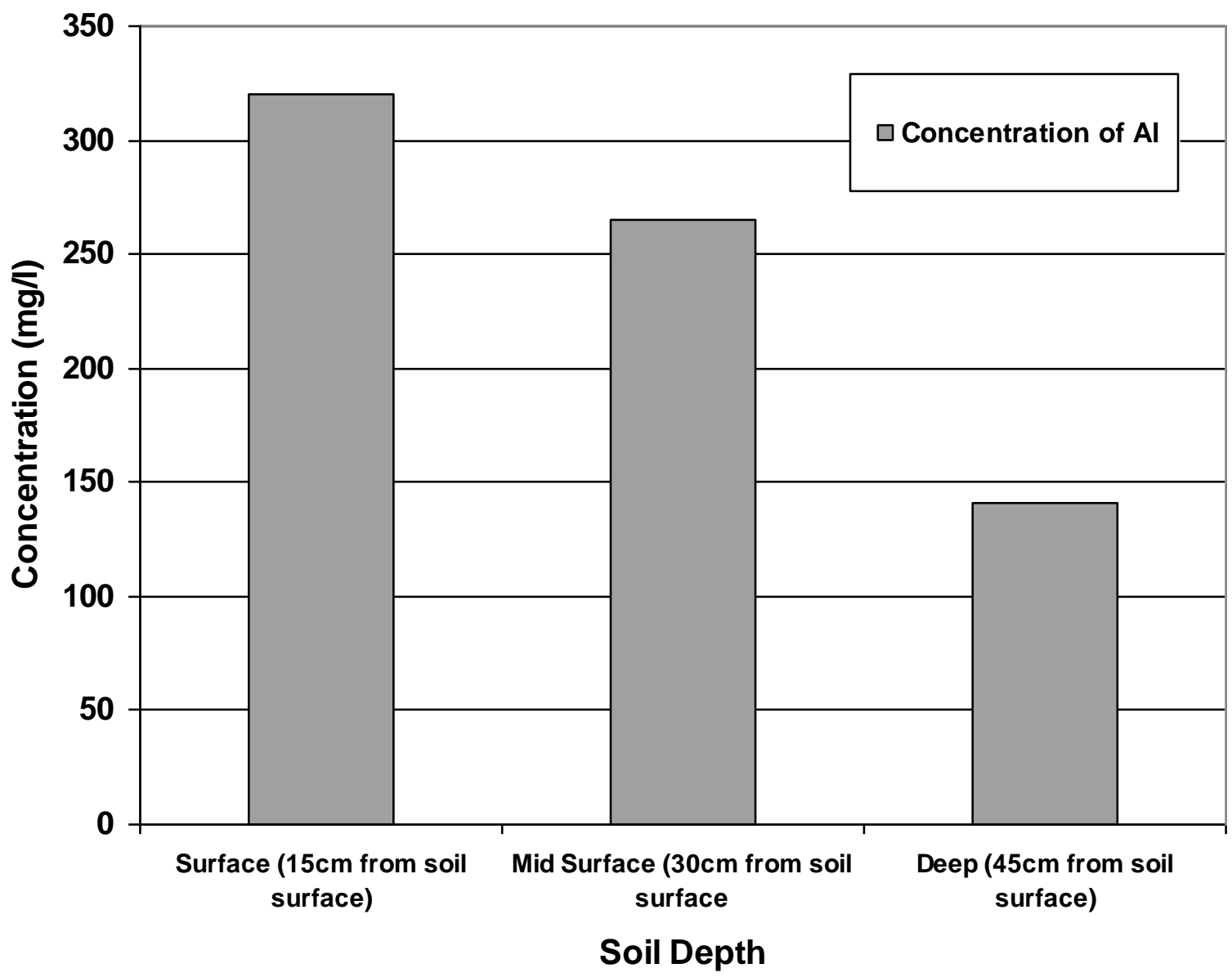

Figure 6: Concentration of $\mathrm{Al}$ at different depth of soil (before soil cover).

A system is an entity that could be spatial (geographic-based, global, regional or national) and temporal (time-based). In one system, each flow through is associated with origin and the destination process is clearly identified. System boundaries define the temporal and spatial delimitation of system under investigation. This was assessed by means of the transfer coefficients and the enrichment or depletion of the $\mathrm{Al}$ elements from the sanitary landfill as spatial boundary.

The system boundary of the system studied is shown in Figure 7, which includes the actual landfilling process. However, the system bounday does not include the collection and transportation of waste to landfill. Some of the influential components contributing to the spatial system boundary, besides the waste unloading are wet precipitation i.e rainfall while major output are mainly landfill gas and leachate. The specific annual leachate generated remains nearly as at constant but only for a period of between 5 and 10 years. Rainwater at JSL is acidic with $\mathrm{pH}$ from 4.48 to 6.82 . Al concentration in rainfall was at $0.03 \pm 20.15 \mu \mathrm{g} / \mathrm{l}$ with 0.0115 tonnes/day of $\mathrm{Al}$ intrusion. The quantity of leachate generated, depends principally on rainfall and the state of the landfill.

The Jeram landfill is taking up most of the $\mathrm{Al}$ can for recycling with approximately 1.39 tonnes/day. The leaching of $\mathrm{Al}$ via both gas and leachate was at 0.46 tonnes/day and 0.14 tonnes/day respectively. From the gas leaching, about 0.34 tonnes/day of $\mathrm{Al}$ was released from the soil and 0.12 tonnes/day through evaporation. In general, about 9.25 tonnes of $\mathrm{Al}$ was introduced into the landfill daily. 


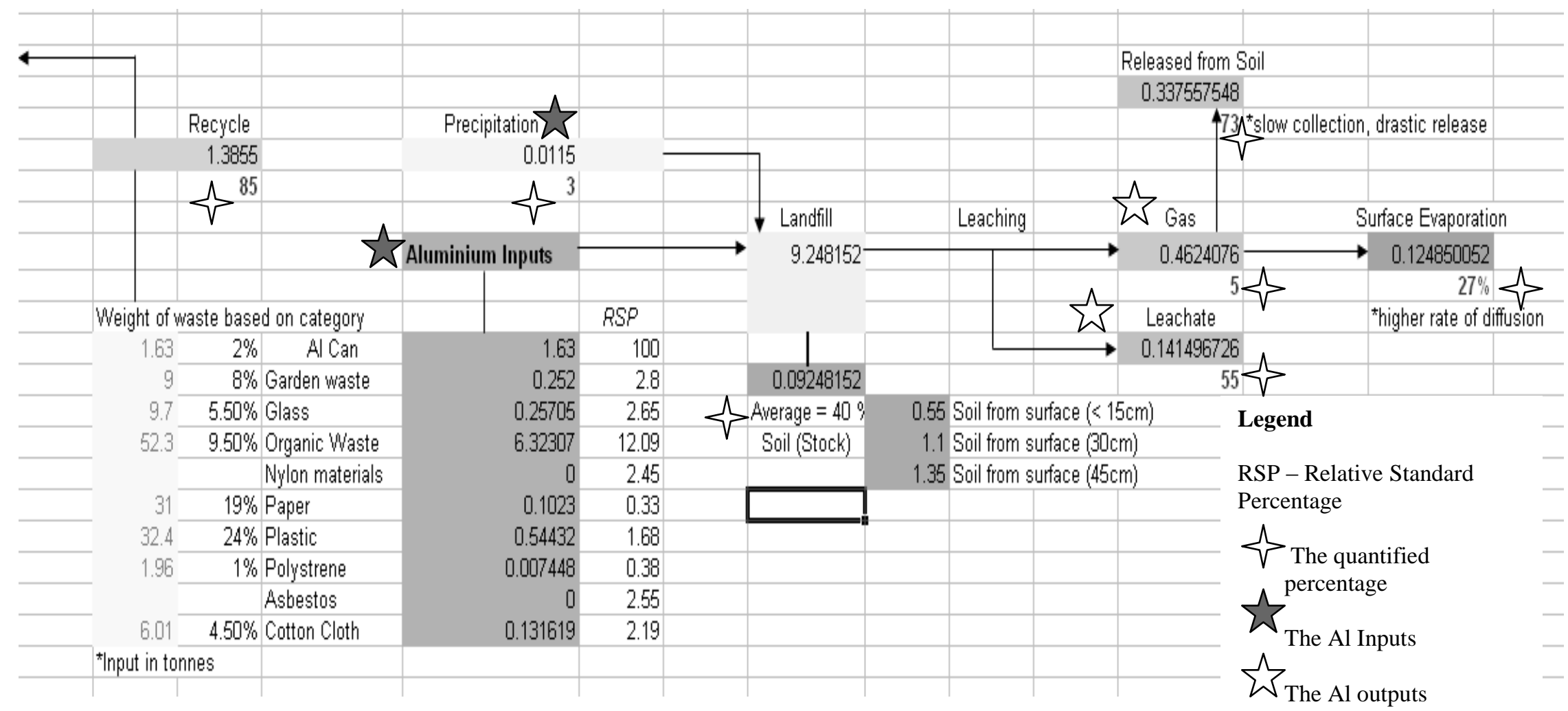

Figure 7: The simulated Al flow for Jeram Landfill using EXCEL (quantified using STAN). Unit resulted in tonnes/day. 


\section{CONCLUSION}

It is relatively new to use this MFA approach in confined yet dynamic system, such as landfill. This paper has quantified Al flow in a sanitary landfill system by considering waste-input output analysis, mass balancing of Al flow within spatial system boundary and the total Substance Flow Analysis (SFA). The results has shown a overall description and better understanding of $\mathrm{Al}$ flows. Recognizing the benefits and the importance of transparency and credibility of the model, will continue improving databases and modeling tools in similar system.

\section{ACKNOWLEDGEMENT}

Auhors would like to thank Jeram Sanitary Landfill Management for support and permission to undertake research and field assistance and assistance and consultancies from Vienna Technical University and University of Malaya for providing research grants (RG002/09SUS), (P0118/2010A) and facilities to conduct lab analysis.

\section{REFERENCES}

1. Brunner P. H. \& Rechberger H. 2004. Practical handbook of material flow analysis. New York: Lewis.

2. Baccini,P. \& Brunner,P.H. 1991. Metabolism of the Anthroposphere. Springer.Berlin

3. Belevi,H. 2002 Material Flow Analysis As a Strategic Planning Tool for Regional Wastewater and Solid Waste Management. Department of Water \& Sanitation in Developing Countries (SANDEC) Swiss Federal Institute for Environmental Science and Technology (EAWAG) Duebendorf.

4. Bergback, B., Johansson, K., Mohlander, U. (2001) Urban Metal flows-A case study of Stockholm. Water, Air and Oil Pollution;Focus $1,3-24$

5. Bertram, M., Graedel, T.E., Rechberger, H., Spatari, S., 2002. The contemporary European Copper cycle: Waste Management Subsystem. Ecological Economics 42, 43-57.

6. Binder,C.R. 1996 The Early Recognition Of Environmental Impacts Of Human Activities In Developing Countries. PhD Dissertation 11748, Swiss Federal Institute of Technology, Zurich Switzerland.

7. Cencic, O. \& Rechberger, H. 2008. Material Flow Analysis with Software STAN. Journal of Environment Engineering and Management 18 (1): 3-7
8. Chen Weiqiang, Shi Lei and Qian Yi. Substance flow analysis of aluminium in mainland China for 2001, 2004 and 200: Exploring its initial sources, eventual sinks and the pathways linking them. Resources, Conservation and Recycling. Vol 54 pg 557-570.

9. Chen Z., Huang C.-Y., Zhao M., Yan W., Chien C.-W., Chen M., Yang H., Machiyama H. \& Lin S. (2011). "Characteristics and possible origin of native aluminum in cold seep sediments from the northeastern South China Sea". Journal of Asian Earth Sciences 40(1): 363-370.

10. Dohmeier, C.; Loos, D.; Schnöckel, H. (1996). "Aluminum(I) and Gallium(I) Compounds: Syntheses, Structures, and Reactions". Angewandte Chemie International Edition 35: 129.

11. Graedel, T.E., Bertram, M., Fuse, K., Gordon, R.B., Lifset, R., Rechberger, H., Spatari, S., 2002. The Contemporary European Copper Cycle: The Characterization Of Technological Copper Cycles. Ecological Economics 42 :9-26.

12. IAI. 2008. Sustainability update 2008. London: IAI. www.worldaluminium.org/cache/f10000286.pdf.

13. John A. S. Green (2007). Aluminum recycling and processing for energy conservation and sustainability. Materials Park, Ohio: ASM International. p. 198.

14. Marlen Bertram, Kenneth J. Martchek and Georg Rombach. 2007. Material Flow Analysis in the Aluminum Industry. Journal of Industrial Ecology. Vol 13 no 5

15. Montangero, A., Anh, N.V., Luthi, C., Schertenleib, R. and Belevi, H. 2004. Building The Concept Of Material Flow Analysis Into The Household-Centred Environmental Sanitation Planning Approach. Proceedings of the Conference on Renewed Efforts to Plan for Sustainable Development. European Academy for the Urban Environment and Technical University Berlin, Germany, 29-30 August 2006.

16. Nikolaas de Jaeger, Walter Verdyck, Augustin Meisters (1997) Method for preparing an aluminium foil for use as a support in lithographic printing plates. Patent Number 5633115

17. Öman, C. 1991. Conversion Phases in Municipal Landfill IVL Report No B1017; IVL, Stockholm, Sweden; 1991.

18. Tchobanoglous G., Theisen H. \& Vigil S. 1994. Integrated Solid Waste Management Engineering Principles and Management Issues. McGraw Hill, US 
19. VUT (Vienna University of Technology) 2000. MFA Manual Guidelines for the use of Material Flow Analysis for Municipal Solid Waste (MSW) Management :Aid in the Management and European Comparison of Municipal Solid Waste Treatment Methods for a global and Sustainable Approach (AWAST Project. Workpackage 1: Waste Matter Aspect EVK4-CT-2000-00015. Vienna University of Technology, Institute for Water Quality and Waste Management, Resource Management Agency, Bureau de Recherches Geologiques et Minieres and Stuttgart University, Institute for Water Quality and Waste Management.

20. World Bank. 2011. Regional Report on Sources. Retrieved from http://data.worldbank.org/ on 10 February 2011. 